\title{
EDUCAÇÃO PROFISSIONAL PÚBLICA NO PONTAL MINEIRO: NOTAS SOBRE O COLÉGIO COMERCIAL OFICIAL (1965-1979)
}

\author{
Sauloéber Társio de Souza \\ Jóbio Balduíno da Silva
}

UFU

\section{RESUMO}

Este trabalho tem como objeto a história do Colégio Comercial Oficial de Ituiutaba (MG), delimitada pelo seu ano de criação em 1965, até sua fusão com outra instituição em 1979, dando início a uma nova etapa. Nesse município mineiro não havia a oferta de ensino profissional público e gratuito, de maneira que o Colégio Comercial Oficial foi importante não apenas pelo seu pioneirismo, mas por desempenhar papel social destacado, pois passou a atender alunos das classes populares que possuíam a expectativa de ascensão social, mas que em muitos casos não se concretizou. Também contou com jovens de classes privilegiadas em seus quadros que não projetavam formação em nível superior. As reflexões sobre as origens dessa escola são articuladas ao contexto socioeconômico nacional sob a ditadura civil-militar que estimulou a educação profissionalizante em suas reformas educacionais como forma de conter a demanda por ensino superior. Para a consecução desse trabalho buscamos fontes bibliográficas, documentais, iconográficas e orais que possibilitaram enfocar essa parte da história da educação profissional pública, uma maneira de se valorizar os estudos voltados para esse tipo de instituição, objeto de escassas pesquisas no campo.

Palavras-chave: educação profissional; ditadura civil-militar; história da educação; Ituiutaba-MG.

\section{PUBLIC PROFESSIONAL EDUCATION IN PONTAL MINEIRO: NOTES ABOUT THE COLÉGIO COMERCIAL OFICIAL (1965-1979)}

\begin{abstract}
The object of this paper is the history of Colégio Comercial Oficial de Ituiutaba (MG), delimited by the year of its beginning by 1965 , until its fusion with another institution in 1979, starting a new phase. In this city of Minas Gerais state there wasn't any offer of public professional education, so that the Colégio Comercial Oficial was important not just about its pioneering, but for its prominent social function, as this institution start to meet students from popular classes who possessed the expected of social ascent, but in many cases it didn't materialized. This school also attented young privileged classes in their classrooms that wouldn't projected to be a graduate student. The reflections on the origins of this school are articulated to the nacional socioeconomic context, that was living in a civil-military dictatorship that stimulated the technical education in their reforms as a way to curb the demand for higher education. To achieve this investigation we acessed bibliographical, documentary, oral and iconographic fonts that allowed focusing on this part of the history of public professional education, a way to value the studies aimed at this kind of institution, object of scant research in the field.
\end{abstract}

Keywords: professional education; civil-military disctatorship; history of education; Ituiutaba-MG. 


\section{Introdução}

Ainda no primeiro momento da colonização brasileira, teve início um tipo de educação profissional de caráter restrito e pouco apontada pela historiografia, tratando-se da instrução ofertada pelos missionários franciscanos:

esses frades já usavam a técnica de percorrer as aldeias indígenas em missões volantes, unindo a catequese à instrução [...] esses franciscanos constituíram recolhimentos que funcionavam em regime de internatos, como verdadeiras escolas que ensinavam, além da doutrina, a lavrar a terra e outros pequenos ofícios (SAVIANI, 2008, p.40).

Contudo, os jesuítas que contavam com a ajuda e a proteção oficial do rei de Portugal e também das autoridades locais, seriam responsáveis pela transformação cultural da população local, adaptando-a aos interesses da Igreja e do Estado português. Em relação ao ensino profissional,

trouxeram irmãos-artesãos, que faziam parte das missões, os quais são responsáveis por fazer surgir nas oficinas as primeiras escolas de aprendizes, com escravos e índios que auxiliavam na manufatura de artigos como roupas, sapatos, utensílios domésticos. Constituir-se-iam assim os primeiros fundamentos da educação profissional no Brasil, dedicada apenas às classes menos favorecidas (DELPHINO, 2010, p.28).

Distinguiam-se dessa tendência, as corporações de ofícios brasileiras que se manteriam por muitos anos, com juízes de ofícios e exames práticos com altos custos para obtenção do grau de mestre, de maneira que as classes desfavorecidas tinham acesso limitado a ele. A aprendizagem de determinado ofício ficava restrita às corporações e se dava pela transmissão de conhecimentos, seja pela palavra ou observação. Sobre a hierarquia das corporações:

\footnotetext{
As corporações tinham uma hierarquia, que funcionava também como uma espécie de "currículo" da verdadeira "escola de artífices" em que se constituía: na base dessa hierarquia estavam os aprendizes; no topo, os mestres; entre os primeiros, que se formavam sob a orientação dos últimos, e estes, que detinham os direitos corporativos plenos, estavam os oficiais, que executavam a maior parte dos serviços (CASTANHO, 2011, p.6-7).
}

Em 1808, com a chegada da família real e, o Brasil se tornando sede do império Português, foram retirados os obstáculos que impediam o desenvolvimento industrial do país, buscando mudar o cenário de centralização do controle das profissões nas mãos dessas corporações. A manutenção da exploração escravocrata, já abolida em outros países também era um problema a ser superado já que a cultura adquirida ao longo de três séculos de discriminação e desprezo por profissões e trabalhos manuais fizeram com que o Brasil se mantivesse como um país tipicamente rural sem mão-de-obra preparada ou interessada no trabalho manufatureiro. "A solução encontrada na época foi a aprendizagem compulsória, que consistia em ensinar ofícios às crianças e aos jovens, que na sociedade não tivessem outra opção, como era o caso dos órfãos e desvalidos [...]" (SANTOS, 2007, p.207), internados em entidades filantrópicas, arsenais e academias militares onde prestavam trabalhos na condição de artífices. 
Como se pode observar, desde os primórdios da história da educação brasileira o ensino profissional - difundido com maior amplitude, foi aquele ligado às atividades manuais e, por conta da desvalorização desse tipo de trabalho, tornou-se atividade marginalizada relativamente às atividades intelectuais. Tal fator, quando trazido para a formação educacional dos indivíduos, deu origem a um sistema dual de ensino. Essa dualidade reforçou a oposição entre a elite e as massas, onde o primeiro grupo se encaminhava para o ensino científico, com a garantia de continuidade dos estudos em nível superior e, ao segundo, se reservava o ensino profissional de caráter terminal.

De tal modo, procuramos validar a hipótese de que o Colégio Comercial Oficial de Ituiutaba pairou entre dois extremos, pois foi criado e coexistiu com outras escolas de ensino primário e médio do município; tinha caráter de ensino terminal; recebia alunos pobres, em geral, mas não era destinado só a eles. Em seu primeiro ano de existência já no contexto da ditadura civil-militar, estimula-se a expansão da educação profissional a partir de uma visão utilitarista e interessada na educação escolar e sua relação com o mundo do trabalho, portando conotação peculiar sob forte inspiração da "teoria do capital humano."

A teoria do capital humano desempenhou um papel central na certificação e legitimação "científica" de que a escola e as políticas educacionais podiam e deviam ser um mecanismo de integração dos indivíduos à vida produtiva. Mediante a transmissão, difusão e socialização dos conhecimentos e saberes, a escola, afirmavam os teóricos deste campo, contribui para formar o capital humano que, como um poderoso fator produtivo, permite um aumento tendencial das rendas individuais $\mathrm{e}$, consequentemente, $\mathrm{o}$ crescimento econômico das sociedades (GENTILI, 2002, p.53).

Portanto, a educação escolar passaria a ser instrumento capaz de viabilizar o desenvolvimento econômico, transformando-se em temática central nos anos de 1950 e 1960 (PAIVA, 2001). O governo ditatorial não mediria esforços na tarefa de consolidar o capitalismo monopolista brasileiro, estimulando o desenvolvimento da economia por meio da acelerada industrialização do país. Nessa perspectiva, a industrialização do país requeria mão-de-obra treinada ou minimamente especializada e, dessa forma, a formação profissional seria fundamental para o rápido desenvolvimento do Brasil.

O cenário local não divergia do nacional. O Colégio Comercial Oficial de Ituiutaba surge com a finalidade de propiciar a formação de jovens para o mercado de trabalho, gerando-lhes a expectativa de ascensão social por meio da educação para o trabalho, mas jovens de classes privilegiadas também passariam por suas salas de aula. Destaca-se que o município de Ituiutaba era considerado na década de 1960 um polo regional de comércio e indústria de beneficiamento, tendo o arroz como principal atividade econômica e, portanto, nessa condição, com proeminente necessidade de mão-de-obra. É preciso apontar as estratégias por detrás do papel desenvolvido pelo colégio na educação profissional dos jovens da cidade e região, em função de seu pioneirismo já que, até então, não havia outros estabelecimentos de ensino gratuitos com a oferta de cursos profissionalizantes. O texto se propõe a agregar elementos a escassa produção científica em torno das instituições escolares voltadas para a profissionalização no Pontal Mineiro.

Dessa forma, a pesquisa que reportamos aqui se apoia em metodologia relativa a história das instituições escolares:

A história das instituições educativas é um domínio do conhecimento em renovação e em construção a partir de novas fontes de informação, de uma especificidade teórico-metodológica e de um alargamento do quadro de análise da história da educação, conciliando e integrando os planos 
macro, meso e micro. É uma história, ou melhor, são histórias que se constroem numa convergência interdisciplinar (MAGALHÃES, 2005, p.98).

O texto está organizado em duas partes, a primeira versando sobre alguns dos princípios legais da educação profissionalizante entre os anos de 1940 a 1970, utilizandonos da leitura de textos científicos especializados, partindo do contexto nacional para o regional. Em seguida, adentramos a história do Colégio Comercial Oficial, analisando os dados encontrados em seu acervo, refletindo sobre as fontes que, em sua maioria, é composta por documentação impressa, tais como leis, ofícios, livros de atas de matrícula e resultados finais, livros de posse de diretores e professores, estatutos, regimentos e relatórios diversos do recorte temporal em questão.

\section{Marcos Legais da Educação Profissional: do contexto macro ao regional}

Na Segunda República, o que mais se destacou em relação à educação profissional, sobretudo a partir de 1942, foi a promulgação de Decretos-lei intitulados Leis Orgânicas de Ensino sob o Estado Novo, quando o poder Executivo exercia também as funções legislativas. Em conjunto, esses decretos ficaram conhecidos como Reforma Capanema. ${ }^{1}$

Pelas novas Leis Orgânicas o ensino profissional passa a ser considerado de nível médio e fora dividido em dois ciclos, um básico e o outro técnico; o ingresso nas escolas passaria a depender do exame de admissão. Nesse contexto, a educação brasileira passou a ter o seguinte formato:

Ensino Primário - comum a todos os educandos, não compreendia o ensino de ofícios. Ensino Médio dividido em 2 etapas, $1^{\circ}$ e $2^{\circ}$ Ciclos divididos em 5 segmentos; secundário (propedêutico ao ensino superior) normal, industrial, comercial e agrícola. O primeiro ciclo dos ramos profissionais destinava-se a formar trabalhadores manuais oriundos das classes menos favorecidas (Constituição de 37). Ensino Superior (DELPHINO, 2010, p.9).

É importante ressaltar que pelas Leis Orgânicas os cursos dos ramos profissionais não autorizavam o acesso ao ensino superior, apenas o ensino secundário dava acesso irrestrito a qualquer carreira superior, sendo necessária ao concluinte do ensino profissional a submissão ao exame de admissão o curso propedêutico caso tivesse o intuito de cursar o ensino superior, o que geralmente não acontecia. Sobre a então nova legislação:

No ponto de vista da concepção, o conjunto das reformas tinha caráter centralista, fortemente burocratizado; dualista, separando o ensino secundário, destinado às elites condutoras, do ensino profissional, destinado ao povo conduzido e concedendo apenas ao ramo secundário a prerrogativa de acesso a qualquer carreira de nível superior; corporativista, pois vinculava estreitamente cada ramo ou tipo de ensino às profissões e ofícios requeridos pela organização social (SAVIANI, 2008, p.269).

Essa dicotomia no ensino, com discriminação e marginalização de um dos lados, foi sendo alterada por meio de leis específicas até a Lei de Diretrizes e Bases da Educação Nacional (LDB) de 1961, que proporcionou a equivalência plena dos ensinos a partir do ano de 1962, quando entrou em vigor. Todavia,

A equivalência estabelecida pela Lei 4.024/61, entretanto, não conseguiu superar a dualidade, tendo em vista a permanência de suas redes de ensino no sistema educacional brasileiro, sendo que o ensino secundário 
continuou mantendo o privilégio de ser reconhecido socialmente. Isso fica comprovado quando tomamos por base o quantitativo de matrículas levantado pelas estatísticas da época, ao constatarmos que: dos 1.129.421 alunos matriculados no segundo ciclo, a grande concentração era nas capitais dos estados de São Paulo, Rio de Janeiro, Minas Gerais e Rio Grande do Sul; $50 \%$ das matrículas correspondiam ao secundário: $45 \%$ aos ramos normal e comercial e apenas $5 \%$ aos ramos industrial e agrícola. (SANTOS, 2007, p.219)

Apesar da dualidade e marginalização do ensino profissional, os dados estatísticos do MEC-INEP de 1967 indicam que havia um maior interesse por determinados ramos do ensino técnico, em especial os cursos comercial e normal, cujo fator de atração era o título profissional de nível médio que conferiam o "técnico de contabilidade e o magistério formador do professor/a, respectivamente". Em relação a origem social dos alunos do ensino comercial em São Paulo, 45,7\% pertenciam a classe inferior, 24,8\% a classe média e 14,9\% a classe superior. Já no ensino normal, a distribuição era mais equilibrada, com 20,2\% da classe inferior, 30,6\% da média e 25,8\% da superior (ROMANELLI, 2006, p.206). Ainda segundo essa autora:

[...] "distorções" na estrutura dualista existiram e continuam existindo. É assim, por exemplo, que o $2 .^{\circ}$ ciclo do ensino comercial abrigava e abriga uma população bastante diversificada, enquanto o ensino normal de $2 .^{\circ}$ ciclo, portanto profissional, acabou por transformar-se na escola da população feminina de classe média e superior (ROMANELLI, 2006, p.169).

Nascimento (2006, p.230) também relativiza a marginalização em relação ao ensino profissional, relatando que nas décadas de 1960 e 1970:

Os únicos cursos profissionais do nível médio de ensino que ainda gozavam de algum prestígio naquela época eram os do magistério das Escolas Normais, que formavam as professoras para o ensino primário, os cursos do Colégio Militar, que conduziam a Escola Militar de Formação de Oficiais e eram basicamente destinados a filhos de militares, além de alguns cursos técnicos de contabilidade.

Os dados apontados por esses autores indicam que havia, de certa forma, uma diversificação do público desses cursos ou, uma maior discriminação com os outros cursos técnicos, como o Agrícola, ligado a vida rural, por exemplo. Assim, historicamente, forjouse a dualidade no ensino secundário brasileiro e, consequentemente, a marginalização do ensino técnico, mas como vimos, havia exceções relacionadas ao contexto temporal e/ou espacial.

A ditadura civil-militar promoveria reformas na educação que expressavam sua política autoritária, a partir das orientações teóricas expressas nas leis que vão sendo aprovadas até 1971. Assim, a educação também sofreu com o centralismo do poder militar e "não é, portanto, um fenômeno neutro, mas sofre os efeitos do jogo do poder, por estar de fato envolvida na política (ARANHA, 2006, p.24)".

Entre as reformas aprovadas, uma das primeiras foi a expansão da rede de ensino profissional com a criação de novos cursos nos anos seguintes ao golpe. A expansão no número de vagas e criação de escolas técnicas e científicas acabou por fazer surgir um novo problema, a articulação entre a escola média e a superior, no que tange a incapacidade do sistema educacional superior em absorver os egressos do ensino médio. Dessa maneira, o ensino médio deveria se tornar todo profissionalizante, com o objetivo de reduzir as pressões por vagas na educação superior, medida que não obteve êxito. 
A insatisfação e manifestações dos estudantes levariam a criação de comissão para discutir suas aspirações, o que daria origem a reforma universitária (Lei 5.540/68) que fixou normas de organização e funcionamento do ensino superior e sua articulação com a escola média. A nova lei possibilitou a criação e expansão das universidades públicas mas, muito mais no âmbito privado das associações e fundações (faculdades) isoladas, vistas pelo sistema como uma solução para o problema. Todavia, a ideia central de seleção ao término do ensino médio daqueles alunos mais capazes para a continuação dos estudos em nível superior foi implicitamente citada na lei, mais especificamente na alínea "a", do Artigo 17, que trata dos tipos de cursos a serem oferecidos pelas Instituições de ensino superior: "a) de graduação, abertos à matrícula de candidatos que hajam concluído o ciclo colegial ou equivalente e tenham sido classificados em concurso vestibular ${ }^{2}$ ". Alterava-se assim o modelo de ingresso no ensino superior, passando-o ao modelo do vestibular classificatório existente até os dias de hoje.

Nascimento (2006, p.252) descreve que no parecer da mesma comissão aparecem sugestões quanto aos cursos do ensino médio que, "consideravam [...], além da importância que tinham em si próprios, pois levam os mais capazes à universidade, predispõem os demais ao exercício de ocupações úteis, evitando a marginalização dos que encerram sua escolaridade com o segundo grau." Verifica-se no parecer da comissão o caráter terminal, dual e excludente dado ao ensino médio, em particular ao profissional, que no entender da comissão deveria ter caráter final de estudos e garantia do exercício de atividade profissional que evitasse a marginalização do indivíduo.

O contexto educacional nacional se refletia em Minas Gerais. A educação profissional no estado mineiro remonta à época do Brasil Colônia. Essa província foi a primeira a tentar o ensino público dos ofícios, segundo Fonseca (1961, p.111), foi por meio da Carta Régia de 21 de janeiro de 1812, em que o príncipe regente "manda formar na Capitania de Minas Gerais uma escola de serralheiros, officiaes de lima e espingardeiros para se occuparem de preparar fechos de armas. [sic]" Apesar dos esforços e negociações para a instalação da escola - e fábrica -, em agosto do mesmo ano, por razões ignoradas, foi comunicado ao Governador de Minas Gerais que não progredisse com $o$ estabelecimento. Outras duas escolas, o Colégio para os índios (Decreto de 06 de julho de 1832) e os Institutos de Menores Artífices (Lei n.2228 de 14 de junho de 1876) chegaram a ser postas no papel, mas nunca existiram de fato. Foi criado, na cidade de Serro, pela Lei mineira $\mathrm{n}^{\mathrm{o}} 2.543$, de 6 de dezembro de 1879, um Liceu de Artes e Ofícios destinado à educação profissional dos menores desvalidos. A lei de criação trazia o seguinte texto:

[...] Art. $2^{\circ}$ - o regulamento respectivo será organizado pelo governo sobre as seguintes bases: o curso literário e profissional compreenderá: a) as matérias exigidas no regulamento $\mathrm{n}^{\mathrm{o}} 84$ para escolas primárias do $2^{\circ}$ grau; b) língua francesa; c) aritmética, geometria, plana e desenho linear; d) música vocal e instrumental; e) uma arte ou ofício à escolha do aluno, dentre os que forem ensinados no estabelecimento. Desde logo serão instaladas as oficinas de alfaiate, sapateiro e marceneiro, podendo ser outras criadas, a proporção que se tornarem necessárias, preferindo-se a de ferreiro, e serralheiro, para a qual poderá ser contratado um perfeito mestre nacional ou estrangeiro. (FONSECA, 1962, p.470-1).

Devido as constantes reduções de verbas destinadas ao liceu e a outros fatores, o estabelecimento acabou por ter duração efêmera, deixando de existir em 1886. No mesmo ano, foi criado em Ouro Preto a Sociedade Artística Ouro-Pretana que acabou por dar origem a um Liceu de tipografia e encadernação, instalado nas dependências do Palácio do Governo. 
Até o advento da República, pouco se fez pela educação profissional, em função, sobretudo, da vida rural do país. Todavia, a renovação de ideias, principalmente no campo da industrialização tomou força, em Minas Gerais, por exemplo, nas três décadas seguintes do governo republicano ocorreu um acelerado crescimento de estabelecimentos fabris, o que pressionaria o poder público para a formação de mão-de-obra, tornando-se imperativo o ensino de ofícios. A criação de estabelecimentos escolares profissionais no estado é demonstrada no quadro abaixo, onde se identifica pelos dados uma predominância das escolas profissionais privadas, entre outras informações:

Quadro 1 - Descrição da criação das Escolas de Ensino Profissional no Estado de Minas Gerais a partir da Velha República - 1896-1960

\begin{tabular}{|c|c|c|c|c|c|}
\hline ANO & ESTABELECIMENTO & TIPO & ORIGEM & OFÍCIOS & OBSERVAÇÕES \\
\hline 1896 & $\begin{array}{l}\text { Instituto de Educandos e Artífices } \\
- \text { (funcionariam em seis } \\
\text { circunscrições no território } \\
\text { mineiro). }\end{array}$ & Público & $\begin{array}{l}\text { Lei } \mathrm{n}^{\circ} 203 \text {, } \\
\text { de } 18 \text { de } \\
\text { setembro de } \\
1896 .\end{array}$ & $\begin{array}{l}\text { Armador, } \\
\text { armeiro, abridor, } \\
\text { alfaiate, } \\
\text { carpinteiro } \\
\text { muitos outros. }\end{array}$ & $\begin{array}{lcr}\text { Nunca } & \text { chegaram } & \text { a } \\
\text { funcionar em virtude do } \\
\text { corte de } & \text { despesas } & \text { dos } \\
\text { governos } & \text { que } & \text { se } \\
\text { seguiram. } & & \\
\end{array}$ \\
\hline 1904 & $\begin{array}{l}\text { Liceus de Artes e Ofícios de Ouro } \\
\text { Preto, Diamantina e Montes } \\
\text { Claros. }\end{array}$ & Privado & $\begin{array}{l}\text { Lei } 393 \text { de } \\
19 \text { de } \\
\text { setembro de } \\
1904 .\end{array}$ & - & $\begin{array}{l}\text { Funcionaram r rom } \\
\text { subvenções do Governo } \\
\text { Estadual. }\end{array}$ \\
\hline \multirow[t]{2}{*}{1910} & $\begin{array}{l}\text { Escola de Aprendizes e Artífices } \\
\text { do Estado de Minas Gerais - Belo } \\
\text { Horizonte. }\end{array}$ & Público & $\begin{array}{l}\text { Decreto } \\
7566, \text { de } \\
\text { 23/09//1909 } \\
\text { de Nilo } \\
\text { Peçanha. }\end{array}$ & $\begin{array}{l}\text { Marcenaria, } \\
\text { ourivesaria, } \\
\text { sapataria, ferraria } \\
\text { e carpintaria. }\end{array}$ & 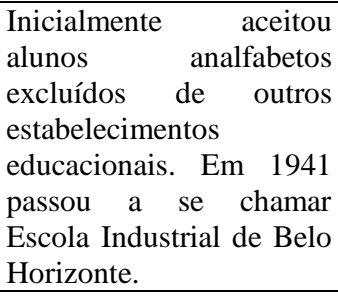 \\
\hline & $\begin{array}{l}\text { Escola Profissional Feminina em } \\
\text { Belo Horizonte. }\end{array}$ & Privado & - & - & $\begin{array}{lr}\text { Funcionou } & \text { com } \\
\text { subvenções do Governo } \\
\text { Estadual. }\end{array}$ \\
\hline 1918 & $\begin{array}{l}\text { Instituto de Ensino Profissional - } \\
\text { anexo a Escola de Engenharia de } \\
\text { Belo Horizonte. }\end{array}$ & Privado & - & $\begin{array}{l}\text { Mecânicos } \\
\text { Eletricistas } \\
\text { Aprendizes de } \\
\text { Ofício. }\end{array}$ & $\begin{array}{lrr}\text { Funcionou } & \text { com } \\
\text { subvenções do } & \text { Governo } \\
\text { Estadual. E foram } \\
\text { extintos os cursos, por } \\
\text { falta de verbas, em 1921 } \\
\text { e 1939, respectivamente. }\end{array}$ \\
\hline 1920 & $\begin{array}{l}\text { Instituição de cursos } \\
\text { complementares (Profissionais). }\end{array}$ & Público & & $\begin{array}{lr}\text { Dois } & \text { cursos } \\
\text { industriais, } & \text { dois } \\
\text { comerciais } & \text { e dois } \\
\text { agrícolas. } & \\
\end{array}$ & $\begin{array}{l}\text { Só funcionou em Sete } \\
\text { Lagoas. }\end{array}$ \\
\hline \multirow{3}{*}{1921} & $\begin{array}{l}\text { Curso de Mecânica Prática da } \\
\text { escola de Engenharia de Belo } \\
\text { Horizontes }\end{array}$ & Privado & - & D & - \\
\hline & $\begin{array}{l}\text { Escola doméstica e Profissional } \\
\text { em Brasópolis }\end{array}$ & Privado & - & - & $\begin{array}{lr}\text { Funcionou } & \text { com } \\
\text { subvenções do Governo } \\
\text { Estadual. }\end{array}$ \\
\hline & $\begin{array}{l}\text { Escola Profissional Delfim } \\
\text { Moreia e m Pouso Alegre }\end{array}$ & Privado & - & - & $\begin{array}{lr}\text { Funcionou } & \text { com } \\
\text { subvenções do } & \text { Governo } \\
\text { Estadual. } & \end{array}$ \\
\hline 1927 & $\begin{array}{l}\text { Escolas Profissionais em Lafaiete } \\
\text { e Moreira, da Estrada de Ferro } \\
\text { Central do Brasil (EFCB) }\end{array}$ & Privado & - & $\begin{array}{l}\text { Preparo } r \text { de } \\
\text { pessoal para a } \\
\text { atividade férrea. }\end{array}$ & Extintas em 1929. \\
\hline 1928 & $\begin{array}{l}\text { Liceu de Uberaba, ou Instituto } \\
\text { Politécnico de Uberaba. }\end{array}$ & Público & - & 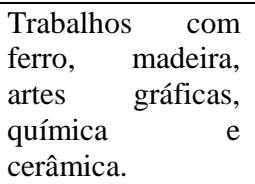 & $\begin{array}{l}\text { Escola de Fidelis Reis } \\
\text { construída e tida como } \\
\text { patrono o industrial } \\
\text { Henry Ford. Foi um } \\
\text { Instituto passageiro. }\end{array}$ \\
\hline
\end{tabular}




\begin{tabular}{|c|c|c|c|c|c|}
\hline \multirow[b]{2}{*}{1937} & $\begin{array}{l}\text { Introdução ao ensino de ofícios: } \\
\text { Escola de Reforma Alfredo Pinto }\end{array}$ & Público & - & $\begin{array}{l}\text { Sapataria, } \\
\text { alfaiataria, } \\
\text { fundição } \\
\text { bronze } \\
\text { marcenaria. }\end{array}$ & $\begin{array}{l}\text { Instituição destinada a } \\
\text { menores delinquentes. }\end{array}$ \\
\hline & $\begin{array}{l}\text { Escola de Preservação Lima } \\
\text { Duarte. }\end{array}$ & Público & - & $\begin{array}{l}\text { Alfaiate, } \\
\text { sapateiro, } \\
\text { tipógrafo, } \\
\text { carpinteiro, } \\
\text { funileiro } \\
\text { marceneiro. }\end{array}$ & $\begin{array}{l}\text { Instituição destinada a } \\
\text { menores delinquentes. }\end{array}$ \\
\hline 1939 & $\begin{array}{l}\text { Escolas Profissionais da EFCB } \\
\text { em Lafaete e Sete Lagoas. }\end{array}$ & Privado & - & $\begin{array}{lr}\text { Preparo } & \text { de } \\
\text { pessoal para a } & \text { a } \\
\text { atividade férrea. }\end{array}$ & - \\
\hline \multirow{3}{*}{1941} & $\begin{array}{l}\text { Escolas Profissionais da EFCB } \\
\text { em Santos Dumont, Belo } \\
\text { Horizonte e Corinto }\end{array}$ & Privado & - & $\begin{array}{lr}\text { Preparo } & \text { de } \\
\text { pessoal para a } & \text { a } \\
\text { atividade férrea. }\end{array}$ & - \\
\hline & $\begin{array}{l}\text { Escola Profissional Getúlio } \\
\text { Vargas em Juiz de Fora }\end{array}$ & $\begin{array}{l}\text { Público } \\
\text { Municip } \\
\text { al }\end{array}$ & - & - & Funcionou por 4 anos. \\
\hline & $\begin{array}{l}\text { Escola Profissional da Rede } \\
\text { Mineira de Aviação, em } \\
\text { Divinópolis. }\end{array}$ & Privado & - & - & - \\
\hline \multirow[t]{2}{*}{1942} & $\begin{array}{l}\text { Instalação do SENAI em Minas } \\
\text { Gerais - Belo Horizonte. }\end{array}$ & Privado & - & $\begin{array}{l}\text { Leitura de } \\
\text { desenhos e } \\
\text { Torneiro. }\end{array}$ & 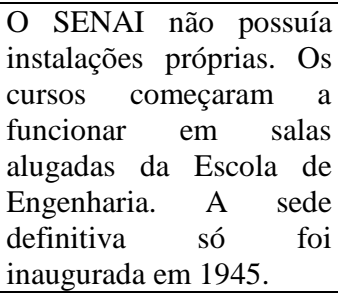 \\
\hline & $\begin{array}{l}\text { Escola Ferroviária em Araguari } \\
\text { da Estrada de Ferro de Goiás. }\end{array}$ & Privado & - & $\begin{array}{ll}\text { Preparo } & \text { de } \\
\text { pessoal para } & \text { a } \\
\text { atividade férrea. }\end{array}$ & - \\
\hline 1943 & $\begin{array}{l}\text { Criação do Curso Técnico de } \\
\text { Mineração e Metalurgia Federal. }\end{array}$ & Público & $\begin{array}{l}\text { Instituído } \\
\text { posterior } \\
\text { pelo } \\
\text { Decreto-Lei } \\
8.300 / 1945 \\
\end{array}$ & 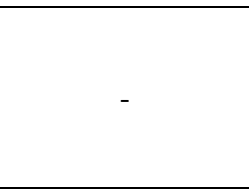 & - \\
\hline 1944 & $\begin{array}{l}\text { Escola de Aprendizagem em } \\
\text { Bicas e em Porto Novo, da } \\
\text { Estrada de Ferro de Leopoldina. }\end{array}$ & Privado & - & - & - \\
\hline 1945 & $\begin{array}{l}\text { Inauguração de escolas SENAI } \\
\text { em Belo Horizonte (já existente } \\
\text { desde 1942), Juiz de Fora, Nova } \\
\text { Lima e Sabará. }\end{array}$ & Privado & - & $\begin{array}{lr}\text { Leitura } & \text { de } \\
\text { desenhos } & \text { e } \\
\text { torneiro. } & \end{array}$ & - \\
\hline 1947 & $\begin{array}{l}\text { Fundação da Escola Técnica de } \\
\text { Química industrial em Ouro Fino }\end{array}$ & Público & $\begin{array}{c}\text { Decreto } \\
26.316 / 1949\end{array}$ & & - \\
\hline \multirow[t]{2}{*}{1948} & $\begin{array}{l}\text { Inauguração da escola SENAI em } \\
\text { Uberaba. }\end{array}$ & Privado & - & - & $\begin{array}{l}\text { Instalou-se no prédio do } \\
\text { Liceu de Uberaba, } \\
\text { idealizado e construído } \\
\text { por Fidelis Reis. }\end{array}$ \\
\hline & $\begin{array}{l}\text { Escola Ferroviária, em Ladainha, } \\
\text { da Estrada de Ferro Bahia a } \\
\text { Minas. }\end{array}$ & Privado & - & $\begin{array}{ll}\text { Preparo } & \text { de } \\
\text { pessoal para a } & \text { a } \\
\text { atividade férrea. }\end{array}$ & - \\
\hline \multirow{2}{*}{1950} & $\begin{array}{l}\text { Inauguração do SENAI em } \\
\text { Guataguases e Itajubá. }\end{array}$ & Privado & - & - & - \\
\hline & $\begin{array}{l}\text { Instituto Técnico Álvaro da } \\
\text { Silveira em Belo Horizonte. }\end{array}$ & Privado & - & $\begin{array}{ll}\text { Técnico } & \text { em } \\
\text { Agrimensura. } & \\
\end{array}$ & - \\
\hline \multirow{2}{*}{1951} & $\begin{array}{l}\text { Escola Ferroviária, da Rede } \\
\text { Mineira de Viação. }\end{array}$ & Privado & - & $\begin{array}{lr}\text { Preparo } & \text { de } \\
\text { pessoal para a } \\
\text { atividade férrea. }\end{array}$ & - \\
\hline & $\begin{array}{l}\text { Escola Pio XII, em Belo } \\
\text { Horizonte. }\end{array}$ & Privado & - & Corte e Costura. & $\begin{array}{l}\text { Funcionava em externato } \\
\text { e destinado ao sexo } \\
\text { feminino. }\end{array}$ \\
\hline
\end{tabular}




\begin{tabular}{|c|l|l|c|l|l|}
\hline 1953 & $\begin{array}{l}\text { Escola Técnica de Juiz de Fora, } \\
\text { da Universidade do Trabalho } \\
\text { Getúlio Vargas. }\end{array}$ & Público & - & - & Nunca funcionou \\
\hline 1957 & $\begin{array}{l}\text { Curso Técnico - anexo à Escola } \\
\text { de Engenharia de Juiz de Fora. }\end{array}$ & Público & - & $\begin{array}{l}\text { Eletrotécnica e } \\
\text { máquinas } \\
\text { motores. }\end{array}$ & $\begin{array}{l}\text { écnico em } \\
\text { Eletrônica. }\end{array}$ \\
\hline $\begin{array}{l}\text { Escola Técnica de Eletrônica } \\
\text { Francisco Moreira da Costa em } \\
\text { Santa Rita do Sapucaí. }\end{array}$ & Privado & $\begin{array}{l}\text { A primeira do país a } \\
\text { oferecer tal } \\
\text { especialização. }\end{array}$ \\
\hline
\end{tabular}

Fonte: quadro elaborado a partir de FONSECA, Celso Suckow da. História do ensino industrial no Brasil. Rio de Janeiro: Escola Técnica Nacional. v. 2. 1962. p. 467-497.

Confirma-se, confrontando e analisando os dados que a educação profissional em Minas Gerais, desde o Império, passando pela República, até o fim da década de 1960, teve pouco ou nenhuma participação dos governos constituídos. No período republicano, conforme esses dados, $65,6 \%$ das escolas instaladas no território mineiro eram privadas, o percentual restante $(34,4 \%)$ era de escolas públicas que tiveram duração efêmera ou nem chegaram a existir, como os Institutos de Educandos e Artífices - que em tese funcionariam em seis circunscrições de Minas, mas nunca foram instalados por falta de recursos e corte de despesas.

No que tange a criação e manutenção de escolas, o governo mineiro se restringiu a fornecer subvenções às escolas particulares para que mantivessem os cursos. As escolas públicas instaladas em Minas, em sua maioria, foram criadas por ações do governo federal ou em casos isolados pelo governo municipal. Coube à iniciativa privada, às indústrias, em especial as de estradas de ferro, a criação de escolas profissionais específicas para a preparação da mão-de-obra necessária ao trabalho e desenvolvimento do estado e do país. Afinal, no início do século XX, Minas Gerais se destacava no cenário nacional, junto com São Paulo, na instalação de indústrias.

Fonseca descreve que apesar do descaso do governo mineiro até então com a educação profissional, a partir da década de 1950, foram firmados convênios com o MEC para que o Ministério construísse novos estabelecimentos de ensino industrial no Estado, arcando com custos de construção e de equipamentos. Em contrapartida o Estado ficaria com o encargo de manutenção da escola. Os convênios resultaram na construção de escolas industriais em Betim, São Sebastião do Paraíso, Diamantina, Curvelo, Além Paraíba, e a Ação Social de Belo Horizonte. Além dessas, foram construídas pelo mesmo convênio as escolas Vocacionais e de Aprendizagem nas cidades de Santos Dumont, Leopoldina e Uberlândia (FONSECA, 1962, p.492-3).

Quanto a escola de Uberlândia, Inácio Filho e Sobrinho (2001, p. 5), ao analisar a expansão do ensino, destacam que "a Escola Vocacional de Uberlândia insere-se numa das faces do processo de massificação da educação, porque além de preparar a mão-de-obra necessária ao setor produtivo, daria solução à massa de desocupados e sem profissão definida, mediante o oferecimento de cursos profissionalizantes." Percebe-se que também em nível local, a formação profissional fora apresentada como solução para os problemas da massa de desocupados, uma formação aligeirada e barata, que levaria a inserção rápida ao mercado de trabalho.

Quanto ao ensino Comercial no Estado de Minas Gerais, na década de 1960, foram criados novos cursos conforme dados da tabela que segue, obtidos no IBGE (1967). Está em destaque o aumento de cursos Ginasial de Comércio no período de 1964-1966 que passou de dois para doze cursos; e do Colegial de Comércio, de um para vinte novos cursos no intervalo de apenas um ano (1965-1966). 
Tabela 1 - Cursos comerciais existentes em Minas Gerais, segundo o ciclo didático e a dependência administrativa - 1964-1966.

\begin{tabular}{|c|c|c|c|c|c|c|c|c|c|c|c|c|c|c|}
\hline \multirow{5}{*}{$\begin{array}{l}\text { UNIDADE DA } \\
\text { FEDERAÇÃO }\end{array}$} & \multirow{5}{*}{ ANOS } & \multicolumn{13}{|c|}{ CURSOS COMERCIAIS } \\
\hline & & \multirow{4}{*}{$\begin{array}{l}\text { Total } \\
\text { geral }\end{array}$} & \multicolumn{6}{|c|}{ Ginasial } & \multicolumn{6}{|c|}{ Colegial } \\
\hline & & & \multirow{3}{*}{ Total } & \multicolumn{5}{|c|}{$\begin{array}{c}\text { Segundo a dependência } \\
\text { administrativa }\end{array}$} & \multirow{3}{*}{ Total } & \multicolumn{5}{|c|}{$\begin{array}{c}\text { Segundo a dependência } \\
\text { administrativa }\end{array}$} \\
\hline & & & & \multicolumn{4}{|c|}{ Público } & \multirow[b]{2}{*}{$\begin{array}{l}\text { Parti- } \\
\text { cular }\end{array}$} & & \multicolumn{4}{|c|}{ Público } & \multirow[b]{2}{*}{$\begin{array}{l}\text { Parti } \\
\text { cular }\end{array}$} \\
\hline & & & & Total & $\begin{array}{c}\text { Fe- } \\
\text { deral }\end{array}$ & $\begin{array}{l}\text { Esta } \\
\text { dua }\end{array}$ & $\underset{\text { cipal }}{\text { Muni- }}$ & & & Total & $\begin{array}{c}\mathrm{Fe}- \\
\text { deral }\end{array}$ & $\begin{array}{l}\text { Esta- } \\
\text { dual }\end{array}$ & $\begin{array}{c}\text { Muni- } \\
\text { cipal }\end{array}$ & \\
\hline \multirow{3}{*}{ Minas Gerais } & 1964 & 278 & 130 & 12 & 一 & 2 & 10 & 118 & 148 & 11 & — & 1 & 10 & 137 \\
\hline & 1965 & 286 & 136 & 15 & - & 4 & 11 & 121 & 150 & 13 & - & 1 & 12 & 137 \\
\hline & 1966 & 302 & 136 & 18 & 1 & 12 & 5 & 118 & 166 & 30 & - & 20 & 10 & 136 \\
\hline
\end{tabular}

Fonte — Anuário estatístico do Brasil 1967. Rio de Janeiro: IBGE, v. 28, 1967.

Como vimos até aqui, o ensino profissional tem sido concebido desde a colônia como pejorativo e destinado, com algumas exceções relacionadas a natureza do curso, a parcela pobre da população. Essa tendência se refletiu mesmo nos lugares mais distantes dos grandes centros de poder e indústria, em cidades do interior como Uberlândia e Ituiutaba, situadas no Triângulo Mineiro.

\section{Origens do Colégio Comercial Oficial de Ituiutaba}

Semelhante ao contexto nacional, o município de Ituiutaba passava na década de 1960 por um processo acelerado de urbanização, industrialização e desenvolvimento econômico. A expansão das lavouras, em especial a cultura do arroz, projetou o município nacionalmente com o título de "Capital do Arroz", conforme relatado por Humberto Guimarães na Enciclopédia dos Municípios Brasileiros.
A principal atividade do município é a agricultura. As terras de Ituiutaba e do ex-distrito de Capinópolis são reputadas entre as mais ferazes do mundo, comparadas segundo Humboldt, Sainte-Hilaire e Edward Miliward, às da Ucrânia, na Rússia, e às do Vale do São Lourenço, no Canadá. O cultivo em toda a zona obedece a um alto nível de mecanização, possuindo Ituiutaba mais de meio milhar de tratores, bem como numerosas colhedeiras de arroz, o que lhe vale o título de "capital do arroz (BRASIL, 1959, p.306)".

Novais (1974, p.33) descreve ainda que "outras indústrias vieram aos poucos aumentar o ritmo industrial de Ituiutaba, principalmente no que se refere ao setor rizicultura, contando atualmente com mais de 100 máquinas de beneficiar arroz e seus subprodutos." Esse processo também pode ser observado pela análise dos dados sobre o aumento expressivo na produção de arroz, milho e algodão, da década de 1950 para a de 1960, representando um aumento de $433 \%, 375 \%$ e $170 \%$ desses produtos, respectivamente.

A rápida expansão na indústria e comércio e a população migrante do campo para a cidade, somada aos grupos de nordestinos fugindo da seca em paus-de-arara e buscando melhores condições de vida e trabalho, aumentaram a demanda por serviços públicos (SILVA, 1997). Em Ituiutaba foram construídas novas redes de energia e luz e um novo serviço de abastecimento de água com grande capacidade de captação e tratamento. 
Na saúde, a cidade contava com dez estabelecimentos, entre casas de saúde e hospitais, sendo dois deles estabelecimentos públicos de saúde. Com esses serviços, o município possibilitou a parcela urbana de seus moradores melhores condições de vida e capacidade de expansão para as indústrias. Em 1964 a cidade contava também, com 788 estabelecimentos comerciais, 619 industriais e nove agências bancárias, entre elas as da Caixa Econômica Federal e Estadual (ITUIUTABA, 2001, p.128).

Mas a mudança mais perceptível foi no campo educacional com a grande expansão da rede de escolas públicas no município. Essa implantação de escolas estaduais em Ituiutaba só se acelerou após a década de 1950, ocorrendo inversão entre as esferas públicas e privadas ao que tange a manutenção das mesmas, estabelecendo-se o fim do predomínio das escolas particulares. O ensino profissional era oferecido em colégios confessionais, como o Colégio Santa Teresa fundado pela Congregação das Irmãs de São Carlos Borromeo-Scalabrinianas e com a finalidade de formar moças no magistério (curso Normal) em sua maioria, da elite urbana e rural da época. O Colégio São José também ofereceu o ensino técnico particular, na forma de ginásio Comercial e Técnico em Contabilidade e era, também, tido como colégio para os filhos da elite. Por fim, uma escola laica, o Instituto "Marden" ofereceu no seu Colégio "Barão de Mauá" o curso ginasial e colegial de Comércio até o ano de 1970.

É neste contexto histórico dinâmico, nacional e local, que se insere o Colégio Comercial Oficial de Ituiutaba, no Triângulo Mineiro, popularmente chamado de "Comercial". Essa escola foi criada pela Lei n 3878 de 20 de dezembro do ano de 1965 e teve, no decorrer de sua história, a denominação mudada para Colégio Estadual de Ituiutaba $^{3}$ e, por último e até os dias atuais, para Escola Estadual Professora Maria de Barros (Lei 7896, de 18 de dezembro de 1980).

Quando da criação do Colégio foi noticiado no Jornal Cidade de Ituiutaba (13/jan./1966, Ano I. N. 4) "o presente de natal” para o povo de Ituiutaba:

Figura 1 - Matéria publicada sobre a Criação do Colégio Comercial em Ituiutaba.

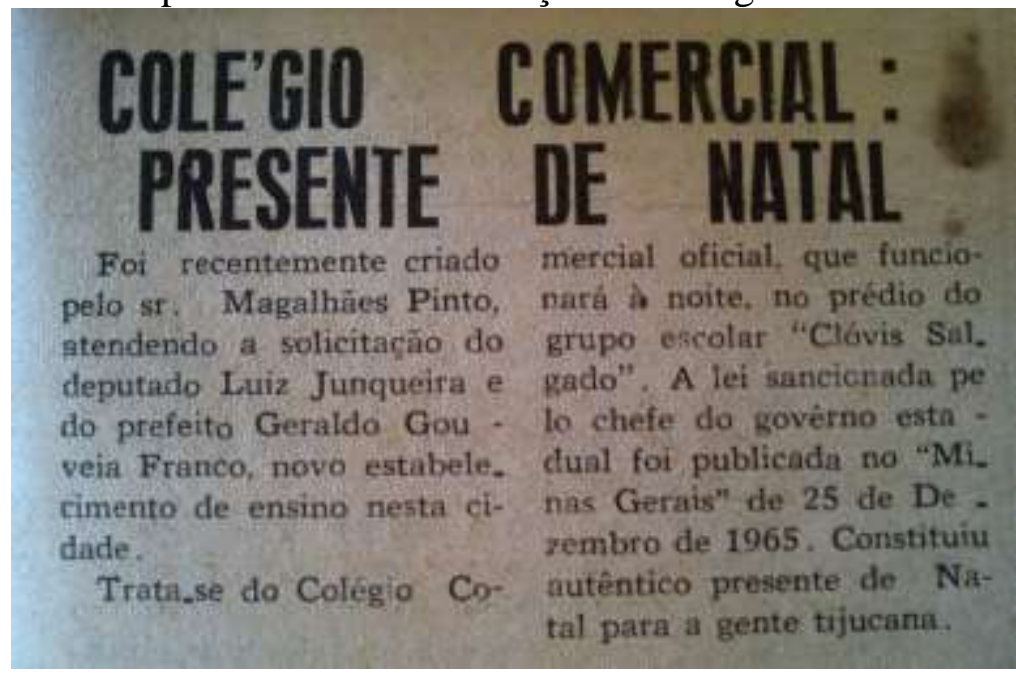

Fonte: Acervo de Jornais do arquivo da Fundação Cultural de Ituiutaba.

O colégio foi criado sem possuir sede própria e nem previsão de construção da mesma. A solução, típica e comum para o período ${ }^{4}$, foi o uso compartilhado de espaço físico com outras escolas. O "Comercial" funcionou no primeiro ano de existência anexado ao Grupo Escolar Governador Clóvis Salgado e a partir do segundo ano, "como houve um pequeno crescimento no número de alunos, alocou parte deles em salas da Escola Rotary, que era perto (BARROS JUNIOR, 2012)." As duas escolas foram criadas na cidade de 
Ituiutaba no ano de 1956. A época, a Escola Rotary situava-se na Rua 36, entre as Avenidas 5 e 5-A, no bairro Progresso. Um prédio modesto, precário, como se vê na figura que segue.

Figura 2 - Prédio antigo da Escola Rotary/Colégio Comercial - Imagem da inauguração da escola em 1956.

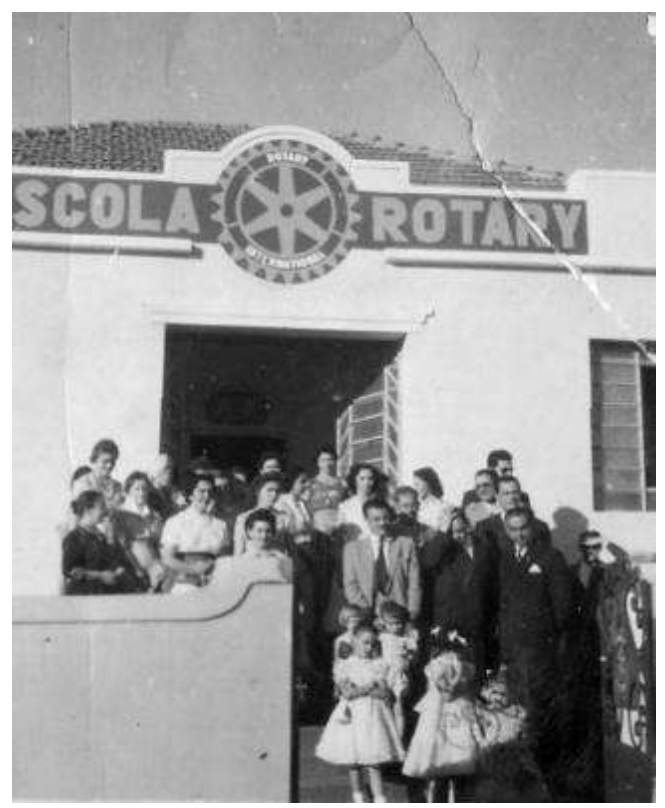

Fonte: Arquivos da Escola Rotary

A estrutura da Escola suscita discussões acerca da importância do espaço escolar no processo de ensino-aprendizagem. Viñao Frago (2000, p.98) remonta ao higienismo para justificar a importância de prédios e espaços bem adaptados às necessidades escolares, salas ventiladas, sanitários, pátios com espaços abertos e a forma do mobiliário, tudo com vistas a se evitar a fadiga escolar e conseguir o máximo de rendimento escolar e físico. As escolas Rotary e Clóvis Salgado eram dedicadas à educação infantil, com salas adaptadas e mobiliário destinado a esse grupo específico. Portanto, com essa estrutura, como atender as necessidades do corpo discente e docente no que tange as necessidades de ensino? Como conviver nesses espaços com públicos tão diferentes? Como crianças e adultos compartilhariam as salas, mobiliários e sanitários? É certo que tais instalações tinham impacto, especialmente, sobre a identidade do colégio Comercial, já que os alunos dessa escola é que eram anexados a outra instituição de ensino fundamental.

Sobre a sede do colégio, não houve a contrapartida provida pelo município como previa a lei estadual no. 3878 (1965), que criou o colégio, pois o poder público municipal não doou o prédio ou mesmo ajuizou o aluguel de algum espaço. Mesmo assim foi autorizado o funcionamento do comercial por meio da Portaria $\mathrm{n}^{\circ} 132$, em que "atendendo a que foram cumpridas as exigências estabelecidas [...] resolve: Art. $1^{\circ}$ - É concedida autorização para o funcionamento do colégio Comercial Oficial de Ituiutaba [...]", Portaria no. 132 datada de 23 de fevereiro de 1966.

Com muitas demandas e recursos escassos no campo educacional, o Colégio Comercial funcionou como anexo e bipartido nas estruturas das duas instituições por longos 8 anos, conforme pode-se ver em relato na ata de reunião de docentes do dia 12 de fevereiro de 1970, sobre a "mudança de outras classes para o grupo escolar Rotary, ficando no Grupo Clóvis Salgado as duas $1^{\text {as }}$ (primeiras) séries. [...]"5 As mudanças das salas de 
aulas foram gradativas até que em 1973, quando a Escola Rotary se mudou para nova sede e levou integralmente o Colégio Estadual de Ituiutaba, o "Comercial". Apesar da mudança para o novo prédio, amplo e com estrutura projetada para o espaço escolar, ter integrado o colégio Comercial e melhorado as condições de ensino, o uso compartilhado com a Escola Rotary perduraria até o ano de 1979.

O livro de posse revela que o corpo docente da escola nos seus primeiros anos de existência era composto em sua maioria por professores contratados temporariamente para prestar serviços naquele estabelecimento. Essa afirmação se comprova por meio da análise dos anexos ao Ofício 13/70, datado de 20 de maio, que encaminhava a Delegada de Ensino de Uberlândia, entre outros relatórios, o "Quadro de Orçamento - Modelo 2" que consta as despesas do estabelecimento daquele ano, sendo relacionados os gastos com 17 professores extranumerários (não concursados), $\mathrm{Cr} \$ 222,35$ por professor; uma professora primária designada, salário de Cr\$274,03 por mês; e um Diretor com salário de Cr\$670,00 por mês. No ano seguinte, o mesmo relatório foi enviado anexo ao Ofício $\mathrm{s} / \mathrm{n}^{\mathrm{o}}$, protocolado em $2 / 11 / 71$, onde constam as despesas do estabelecimento com a contratação de 15 professores extranumerários, com salário de $\mathrm{Cr} \$ 311,98$ por professor/mês; um professor nomeado com o salário de Cr\$ 462,00 por mês; um secretário, Cr\$ 356,40 por mês e um Diretor com salário de Cr\$763,80 por mês. Observa-se uma ampliação de mais de $40 \%$ nos salários dos professores, indicando necessidade de atualização salarial também em função da inflação do periodo.

Quanto ao grande número de professores contratados e os poucos concursados, o colaborador e ex-diretor Barros Júnior (2012) informou que não havia professores habilitados para atuar na educação:

[...] nos começamos, na verdade não existia ninguém em condições, assim, de registro de professor. Ituiutaba não tinha escola superior, a região em si não tinha escola superior. Então a gente contratava aqueles que tinham certas práticas, um certo nível de estudo. Às vezes advogados, para dar aula de português; alguns professores das escolas normais. Tanto é que posteriormente, esse pessoal passou a estudar, muitos fizeram pedagogia, letras, aqui na faculdade, posteriormente, pós-graduação e criaram titularidade dentro da área educacional. [...] mas naquela época todos estávamos carentes. [...] pois o professor tinha que conseguir a autorização de professor em Belo Horizonte, ter curso superior e só depois poderia conseguir o registro de professor. Caso não possuísse curso superior teria que se submeter a exame de suficiência.

A fala do colaborador reflete o momento de grande expansão da rede pública de ensino, promovida pela ditadura, mas em condições precárias, já que não havia professores qualificados para assumirem as novas escolas e salas de aula que cresciam em número. Para o contrato de professores, além do exame de suficiência a ser realizado após o primeiro ano de contrato, eram necessários os seguintes documentos: “a) Requerimento ao Inspetor do Departamento de Ensino Comercial; b) Atestado de dois professores registrados; c) quitação militar; d) quitação eleitoral; e) diplomas de cursos realizados; f) atestado de vacinas e atestado médico; g) folha corrida.",

Já o ingresso dos alunos na escola acontecia por meio de exame de admissão, aplicado aos alunos no $1^{\mathrm{o}}$ ciclo $\left(1^{\mathrm{a}}\right.$ Série antes da Lei 5692/71). Os interessados no curso Técnico de Contabilidade só disputavam a vaga em exame de seleção quando o número de candidatos ingressantes do segundo ciclo, que não eram egressos do primeiro ciclo da escola, superava o número de vagas. A respeito do problema de vagas, segundo Barros Júnior (2012): 
sempre procurou colocar os candidatos. [...] nós tínhamos um problema de carteiras, então eu falava: você faz a carteira que eu te ponho. E foi um negócio assim, para ajudar mesmo, por que eram trabalhadores. Pessoas que trabalhavam no comércio de Ituiutaba e queriam fazer Contabilidade. O sujeito chegava lá pedindo de toda maneira, implorando para estudar, por que não tinha onde estudar.

Essa demanda acentuada, tinha relação com o movimento de urbanização do país, invertendo as estatísticas entre rural e urbano no que se refere a população. Ampliando a discussão sobre a origem social dos alunos, o ex-diretor descreveu que o aluno do Comercial

Era médio pobre, para pobre, muito depois e que eu recebi alguns alunos que tinham condições financeiras, chegamos a ter filhos de pais ricos que vinham fazer o curso Técnico de Contabilidade, mas isso foi mais para frente. O grosso mesmo foram pessoas de poucos recursos. Era a única escola [Comercial] que nós tínhamos gratuita. E que os alunos que podiam, filhos dos pais que tinham condições financeiras, eram mandados para fazer o científico e a faculdade em Belo Horizonte, Uberaba e São Paulo. Os pais faziam esse esforço, gastavam dinheiro. Em Ituiutaba, eram mais comuns os cursos Normal e Contabilidade, ai não tinha opção, ou ele [o candidato] era Normalista ou era Contador. $\mathrm{O}$ Normal era para as mulheres, não tinham homens, quando tinham eram muito poucos. O que tinha mais eram os alunos para o curso Técnico de Contabilidade. (BARROS JUNIOR, 2012).

O depoimento do colaborador confirma que o Colégio Comercial Oficial de Ituiutaba, especialmente em seu início, tinha como público jovens trabalhadores das classes populares, contudo, esse perfil se alteraria com o passar dos anos. Pode-se inferir que existia um sistema dual de ensino, mas mesmo fazendo parte dele, os cursos desse colégio tinham importância na formação dos jovens da cidade e da região (alunos viajavam diariamente das cidades de Capinópolis e Santa Vitória), no contexto da Ituiutaba da década de 1960, em que não havia o ensino superior e nem a oferta de outros tipos de cursos profissionais uma vez que esses cursos eram de implantação barata e de grande tradição em nosso sistema educativo.

O problema estava mesmo na falta de oportunidades educacionais que limitava os horizontes dos indivíduos ao que a cidade oferecia no campo educativo. A oferta limitada aos dois cursos expressa também uma relação de gênero, conforme vimos no depoimento do ex-diretor: as alunas cursavam o normal, enquanto os alunos o Técnico em Contabilidade, muito embora, houvesse alunas também nesse último e alunos no primeiro.

Independente da origem social ou gênero dos alunos, a rotina do colégio compreendia o envolvimento nas suas atividades culturais e esportivas que eram importantes no cotidiano da escola. A esse respeito Barros Júnior (2012) afirmou priorizar três aspectos na escola:

(...) o educacional, o social e o esportivo. Não existe uma escola sem esses três aspectos. Quem nunca viu diretores que se preocupavam somente com a educação; o esporte muito pouco e o social, então, se omitiam. (...) O comercial organizava festas sadias, participava dos jogos estudantis com times de futebol de salão formados por moços e de vôlei pelas moças. E isso era muito importante para a formação do indivíduo.

Além dos jogos e outras festas, os alunos do Colégio eram assíduos nos desfiles de 7 de setembro - comemoração da independência do Brasil - e do dia 16 de setembro, em 
comemoração da emancipação político-administrativa da cidade de Ituiutaba. Encontramos no arquivo da escola uma foto do desfile do dia 16 de setembro de 1967, em que os alunos participaram da parada, em um carro que carregava o símbolo do colégio.

Figura 3 - Participação dos alunos do Colégio Comercial Oficial de Ituiutaba no desfile de

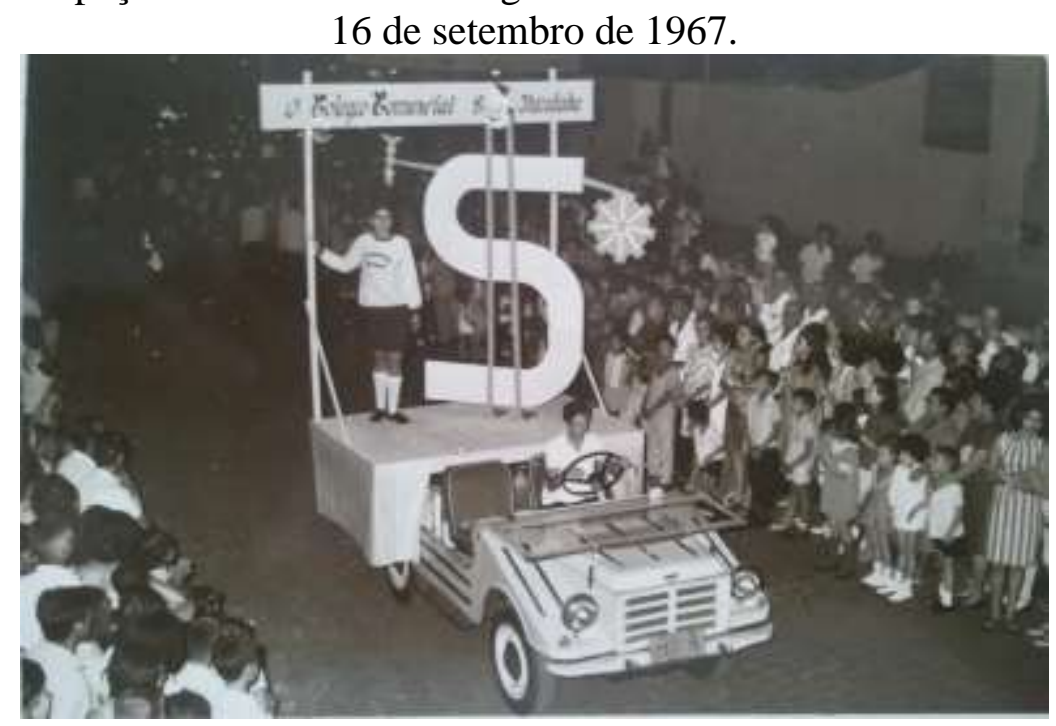

Fonte: Arquivos do Colégio

Nota-se o grande público presente na parada e a peculiar mascote do colégio, um cifrão que carregava no braço direito o Caduceu, símbolo dos Contabilistas e no esquerdo uma roda dentada, que representa o trabalho, e faz parte da simbologia da economia. A mascote também utilizava o capacete com asas do Deus Mercúrio, da mitologia romana, que era associado às relações comerciais e a venda.

Ao ser interpelado, o ex-diretor sorriu e disse que a mascote que estava no carro do desfile era uma criação sua. Segundo ele, "o cifrão estava ligado à economia e a contabilidade, e na criação utilizou toda uma simbologia para criar o cifrão personalizado (BARROS JÚNIOR, 2012)." A mascote entrou para a história do colégio e recebeu o apelido de "Zé Cifrão". O símbolo teve tanta importância que foi inserido dentro do triângulo da logomarca da Escola, que é utilizada nos documentos e uniformes dos alunos da Escola Maria de Barros (ex Comercial) ainda hoje. A imagem é bastante reveladora e provoca a associação entre o estudo e renda, ideia bastante propalada a partir dos anos de 1950, pela teoria do "Capital Humano", a ilustração iria além, transformando o próprio indivíduo em dinheiro. 
Figura 4 - Logomarca da Escola Estadual Professora Maria de Barros, um triângulo, rodeado pelo nome da escola e com a mascote apelidada de "Zé Cifrão" no centro.

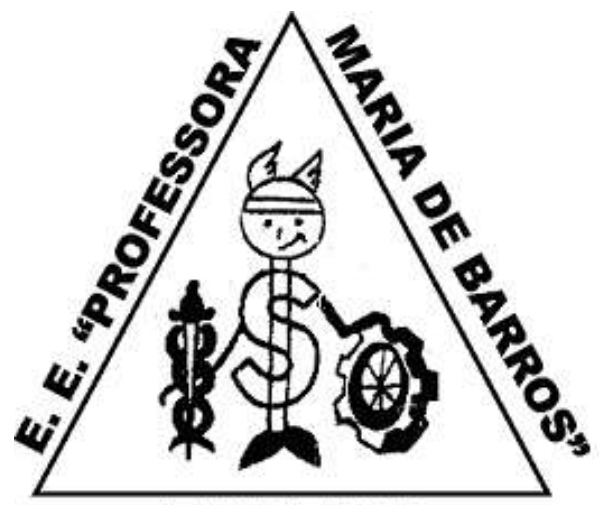

ITUIUTABA

Fonte: Arquivos da Escola

Essa expectativa de ascensão social, via escola, refletiria no aumento do número de alunos dessa instituição ao longo do tempo. Vejamos a análise de dados numéricos e de índices percentuais de matrículas efetivadas e canceladas, alunos ingressantes, reprovados em $1^{a}$ e $2^{a}$ época e evasão escolar. Observemos os dados oriundos da tabulação dos livros de Atas de resultados do Ginásio Comercial que contemplam, além das notas e da quantidade de alunos, as reprovações e desistências.

Tabela 2 - Quantidade de matrículas no curso de Ginasial de Comércio - 1966-1979.

\begin{tabular}{|c|c|c|c|c|c|c|c|c|c|c|c|c|c|c|c|c|}
\hline Legislação & Série & Turma & 1966 & 1967 & 1968 & 1969 & 1970 & 1971 & 1972 & 1973 & 1974 & 1975 & 1976 & 1977 & 1978 & 1979 \\
\hline \multirow{5}{*}{$\begin{array}{l}\overline{0} \\
\frac{0}{3} \\
\bar{a}\end{array}$} & $1^{\mathrm{a}}$ & $\mathbf{A}$ & 42 & 46 & 55 & 53 & 47 & 47 & 52 & & & & & & & \\
\hline & & B & & & & 52 & 46 & 49 & 49 & & & & & & & \\
\hline & $2^{a}$ & Única & 34 & 41 & 38 & 55 & 49 & 55 & 52 & & & & & & & \\
\hline & $3^{a}$ & Única & 26 & 37 & 42 & 46 & 48 & 48 & 52 & & & & & & & \\
\hline & $4^{\mathrm{a}}$ & Únida & 14 & 26 & 32 & 37 & 39 & 43 & 33 & & & & & & & \\
\hline \multirow{5}{*}{ 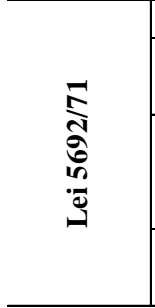 } & $5^{a}$ & Única & & & & & & & & 47 & 45 & 50 & 57 & 58 & 59 & 61 \\
\hline & $6^{\mathrm{a}}$ & $\begin{array}{l}\text { A } \\
\mathbf{B}\end{array}$ & & & & & & & & 46 & 43 & 50 & 49 & 49 & 57 & $\begin{array}{l}61 \\
62\end{array}$ \\
\hline & & $\mathbf{A}$ & & & & & & & & 43 & 43 & 47 & 46 & 53 & 55 & 56 \\
\hline & $7^{\circ}$ & $\begin{array}{l}\text { B } \\
\text { C } \\
\end{array}$ & & & & & & & & & & & & & & $\begin{array}{l}53 \\
53 \\
\end{array}$ \\
\hline & $8^{a}$ & $\begin{array}{l}\text { A } \\
\text { B }\end{array}$ & & & & & & & & 41 & 42 & 42 & 46 & 44 & 48 & $\begin{array}{l}60 \\
60 \\
\end{array}$ \\
\hline \multicolumn{3}{|c|}{ TOTAL DE ALUNOS } & 116 & 150 & 167 & 243 & 229 & 242 & 238 & 177 & 173 & 189 & 198 & 204 & 219 & 466 \\
\hline
\end{tabular}

Fonte: Livros no 1 e 2 de registro de Atas de resultados dos alunos do curso Ginasial de Comércio -1966-1979 Arquivo da Escola

Nota-se que no ano de 1966, no primeiro ano de funcionamento do colégio, o número de matrículas do Ginásio foi expressivo. Foram formadas quatro turmas, uma de cada série do ensino primário que totalizaram o número de 116 alunos. A turma de maior quantidade foi a $1^{\text {a }}$ Série, ou seja, os ingressantes, com 42 alunos. Todavia, a formação de turmas de $2^{\mathrm{a}}, 3^{\mathrm{a}}$ e $4^{\mathrm{a}}$ séries já no primeiro ano de criação do colégio denota que houve transferências de alunos oriundos de outras escolas. Levando em consideração que na época somente o Educandário Ituiutabano oferecia ensino Ginasial de Comércio gratuito, um curso ainda não autorizado, podemos inferir que a maioria desses alunos da $2^{\mathrm{a}}, 3^{\mathrm{a}}$ e $4^{\mathrm{a}}$ 
séries foram transferidos do ensino privado. A respeito disso, Barros Júnior (2012) esclareceu que:

[...] houve realmente a absorção de alunos de outras escolas, inclusive das privadas. O Marden [escola privada da cidade] começou a entrar em uma situação difícil, por falta de alunos, houve uma carência de alunos, então naquela época o Dr. Álvaro [proprietário da escola] estava tendo dificuldades de manter o curso técnico. E nós absorvermos, também, vários alunos, quer dizer, ampliamos as nossas salas e conseguimos dar uma... Uma solução nessa problemática do Instituto Marden, então nós engrossamos a escola com um pouco mais de alunos (...).

Retornando a análise dos dados das matrículas, até o ano de 1968, comparando o primeiro ano letivo com esse, verificamos um aumento de $44 \%$ no número de alunos matriculados. Após esse período o número de alunos cresceu até 1972, momento em que a escola já havia dobrado a matrícula de alunos em relação ao primeiro ano de sua existência, contando com duas turmas de $1^{\mathrm{a}}$ série, A e B, desde o ano de 1969. Os números demonstram que o ensino profissionalizante gratuito era muito procurado e se consolidava como alternativa para conclusão dos estudos.

A partir de 1972, com o advento da Lei 5692/71 que unificou o ensino primário passando o $1^{\mathrm{o}}$ grau para oito anos de estudos obrigatórios, de forma que as séries de $1^{\mathrm{a}}$ a $4^{\mathrm{a}}$ do ginásio, transformaram-se em $5^{\mathrm{a}}$ a $8^{\mathrm{a}}$ séries do $1^{\mathrm{o}}$ grau. As Atas do Colégio a partir de 1974 não trazem mais a formação do aluno como de "Ginasial de Comércio", mas sim a denominação geral de ensino de $1^{\circ}$ grau. Nos arquivos pesquisados se verificou que as reformas no ensino introduzidas pela citada lei acabaram por refletir na carga horária das aulas e rotinas do colégio, sendo adaptada aos currículos dos cursos a partir do ano de 1974.

Com relação ao número de alunos, um fenômeno que observamos foi a estabilidade nas matrículas no intervalo de 1969 até 1972, onde se manteve uma média de 200 alunos por ano. Contudo, a partir de 1973, ocorre um decréscimo de 25,6\% no número de matrículas interrompendo o crescimento e deixando a média, entre os anos de 1973 e 1978, abaixo do período inicial com queda de matrículas especialmente entre os anos de 1973 a 1975. Quanto a tal fenômeno, podemos considerar como fato motivador da diminuição no número de alunos a transferência do Colégio Estadual de Ituiutaba, o "Comercial", para o novo prédio da escola Rotary, situado no bairro Ipiranga, num conjunto habitacional conhecido como Núcleo da COHAB, região chamada de "Capão da Lagoa", por estar muito próxima de uma lagoa cercada por uma mata fechada, local periférico e de difícil acesso. Tal mudança certamente influenciou na redução do número de alunos, pois a escola se distanciou do centro e de outros bairros da cidade, dificultando o acesso a ela.

O colaborador Iderlindo Joaquim Luzia (2012) disse que iniciou como professor no Colégio Comercial do bairro Ipiranga e que "o acesso era muito difícil, se dava pela Avenida 7; que os alunos tinham que passar pelo cemitério da cidade, por ruas de terra, a pé ou de bicicleta, até chegar no colégio. Tudo isso à noite." Todos esses fatores acabaram por influenciar a procura pelo ensino comercial ginasial provocando diminuição nas turmas com menos de 50 alunos por sala, excetuando-se a dos ingressantes, a $5^{\mathrm{a}}$ série. 
Tabela 3 - Quantidade total de alunos reprovados no curso Ginasial de Comércio, excluindo as matrículas canceladas e os alunos evadidos. - 1966-1979.

\begin{tabular}{|c|c|c|c|c|c|c|c|c|c|c|c|c|c|c|c|c|c|c|}
\hline & & \multirow[b]{2}{*}{$\begin{array}{l}\text { Séries e } \\
\text { turmas }\end{array}$} & \multicolumn{4}{|c|}{\begin{tabular}{|c|} 
Soma de Mat. Canceladas \\
e Desistentes
\end{tabular}} & \multicolumn{4}{|c|}{$\begin{array}{l}\text { Total de Reprovados em } 1^{\mathrm{a}} \\
\text { e } 2^{\mathrm{a}} \text { época e Recuperação }\end{array}$} & \multicolumn{4}{|c|}{$\%$ de Reprovados $^{(1)}$} & \multicolumn{4}{|c|}{$\begin{array}{c}\text { Total de alunos da } \\
\text { turma }\end{array}$} \\
\hline & nos & & $\mathbf{1}^{\mathrm{a}}$ & $2^{\mathrm{a}}$ & $3^{\mathrm{a}}$ & $4^{a}$ & $\mathbf{1}^{\mathrm{a}}$ & $2^{\mathrm{a}}$ & $3^{\mathbf{a}}$ & $4^{a}$ & $1^{\circ}$ & $2^{\circ}$ & $3^{\circ}$ & $4^{a}$ & $1^{\circ}$ & $2^{\circ}$ & $3^{\circ}$ & $4^{a}$ \\
\hline \multirow{12}{*}{$\begin{array}{l}\overrightarrow{0} \\
\stackrel{2}{a} \\
\stackrel{0}{a}\end{array}$} & 1966 & única & 13 & 8 & 4 & 3 & 11 & 5 & 2 & 0 & 37,9 & 19,2 & 9,1 & 0,0 & 42 & 34 & 26 & 14 \\
\hline & 1967 & única & 19 & 12 & 10 & 3 & 18 & 14 & 9 & 0 & 66,7 & 48,3 & 33,3 & 0,0 & 46 & 41 & 37 & 26 \\
\hline & 1968 & única & 19 & 17 & 15 & 5 & 20 & 7 & 3 & 4 & 55,6 & 33,3 & 11,1 & 14,8 & 55 & 38 & 42 & 32 \\
\hline & 1969 & $\mathbf{A}$ & 18 & 22 & 8 & 5 & 16 & 14 & 14 & 5 & 45,7 & 42,4 & 36,8 & 15,6 & 53 & 55 & 46 & 37 \\
\hline & & B & 21 & & & & 27 & & & & 87,1 & & & & 52 & & & \\
\hline & 1970 & $\mathbf{A}$ & 15 & 14 & 6 & 3 & 17 & 14 & 10 & 6 & 53,1 & 40,0 & 23,8 & 16,7 & 47 & 49 & 48 & 39 \\
\hline & & B & 15 & & & & 19 & & & & 61,3 & & & & 46 & & & \\
\hline & 1971 & $\mathbf{A}$ & 7 & 13 & 4 & 6 & 21 & 13 & 20 & 7 & 52,5 & 31,0 & 45,5 & 18,9 & 47 & 55 & 48 & 43 \\
\hline & & B & 14 & & & & 18 & & & & 51,4 & & & & 49 & & & \\
\hline & 1972 & $\mathbf{A}$ & 12 & 10 & 10 & 5 & 22 & 11 & 11 & 2 & 55,0 & 26,2 & 26,2 & 7,1 & 52 & 52 & 52 & 33 \\
\hline & & B & 8 & & & & 21 & & & & 51,2 & & & & 49 & & & \\
\hline & & & $5^{\mathrm{a}}$ & $6^{\mathrm{a}}$ & $7^{\mathrm{a}}$ & $8^{a}$ & $5^{\mathrm{a}}$ & $6^{\mathrm{a}}$ & $7^{\mathrm{a}}$ & $8^{a}$ & $5^{\mathrm{a}}$ & $6^{\mathrm{a}}$ & $7^{\mathrm{a}}$ & $8^{a}$ & $5^{\mathrm{a}}$ & $6^{\mathrm{a}}$ & $7^{\mathrm{a}}$ & $8^{a}$ \\
\hline \multirow{9}{*}{ 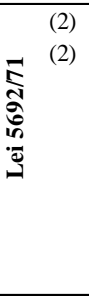 } & 1973 & única & 14 & 16 & 9 & 6 & 8 & 5 & 3 & 1 & 24,2 & 16,7 & 8,8 & 2,9 & 47 & 46 & 43 & 41 \\
\hline & 1974 & única & 9 & 8 & 6 & 0 & 5 & 1 & 0 & 0 & 13,9 & 2,9 & 0,0 & 0,0 & 45 & 43 & 43 & 42 \\
\hline & 1975 & única & 10 & 14 & 2 & 5 & 12 & 7 & 4 & 0 & 30,0 & 19,4 & 8,9 & 0,0 & 50 & 50 & 47 & 42 \\
\hline & 1976 & única & 22 & 16 & 14 & 3 & 10 & 7 & 4 & 5 & 28,6 & 21,2 & 12,5 & 11,6 & 57 & 49 & 46 & 46 \\
\hline & 1977 & única & 21 & 14 & 16 & 7 & 8 & 5 & 2 & 2 & 21,6 & 14,3 & 5,4 & 5,4 & 58 & 49 & 53 & 44 \\
\hline & 1978 & única & 10 & 20 & 17 & 9 & 17 & 6 & 0 & 1 & 34,7 & 16,2 & 0,0 & 2,6 & 59 & 57 & 55 & 48 \\
\hline & 1979 & $\mathbf{A}$ & 26 & 29 & 18 & 20 & 5 & 5 & 8 & 9 & 14,3 & 15,6 & 21,1 & 22,5 & 61 & 61 & 56 & 60 \\
\hline & & B & & 27 & 20 & 21 & & 12 & 7 & 8 & & 34,3 & 21,2 & 20,5 & & 62 & 53 & 60 \\
\hline & & C & & & 24 & & & & 2 & & & & 6,9 & & & & 53 & \\
\hline \multicolumn{3}{|c|}{ TOTAL.............. } & 273 & 240 & 183 & 101 & 275 & 126 & 99 & 50 & 42,8 & 25,1 & 17,5 & 9,9 & 915 & 741 & 748 & 607 \\
\hline
\end{tabular}

Fonte: tabela elaborada pelo autor a partir das atas de notas finais do discentes do Curso Ginasial de Comércio disponíveis no acervo do Colégio.

Notas:

(1) Percentual de reprovados em $1^{\mathrm{a}}$ e $2^{\mathrm{a}}$ época e recuperação, excluídos os Desistententes e Matrículas Canceladas;

(2) Em 1973 e 1974 os alunos tiveram o benefício da recuperação. Antes disso era somente a 2a época. De 1975 até o ano de 1979 não foram encontrados registros de atas com resultados de recuperação e $2^{\mathrm{a}}$ época. Portanto, nesse período, caso os alunos não obtivessem as notas mínimas as reprovações eram diretas.

A tabela aponta o número de discentes reprovados em $1^{\mathrm{a}}$ e $2^{\mathrm{a}}$ épocas e em recuperação no Ginásio Comercial. A nota mínima para aprovação era a média calculada por uma fórmula específica, com pesos diferentes para arguições, trabalhos práticos e exame final. O resultado do cálculo da fórmula não podia ser menor que 50, pois o aluno seria reprovado, ou ficaria de $2^{\mathrm{a}}$ época ou recuperação, se não tivesse conseguido aprovação no máximo em duas disciplinas. A $2^{\mathrm{a}}$ época foi adotada pela escola a partir do ano de 1967 - em 1966 as reprovações foram diretas - para quem obteve resultados abaixo da média. Essa medida, bem como a adoção da recuperação, tinha por finalidade diminuir os índices de repetência escolar, contudo ao analisarmos os dados, verificamos que esses índices eram muito altos, mesmo depois de se excluir os alunos que cancelaram suas matrículas e aqueles que evadiram da escola no decorrer do ano.

As incidências mais expressivas foram verificadas na $1^{a}$ série, seguida das demais séries em que os índices vão diminuindo, mas continuam altos. Encontramos picos elevadíssimos de reprovação, Turma "B" de 1969, em que 87,1\% dos alunos que concluíram o ano escolar foram reprovados. A Turma única de 1967 teve 66,7\% de alunos reprovados e a "B" de 1970, 61,3\%. Os índices mantêm, em média, 55\% de reprovação na primeira série no período de 1966 a 1972. Mais a frente, no período de 1973 a 1979, o índice de reprovação da $1^{\circ}$ série caiu para a média de $24 \%$ de reprovação, contudo, entre 1966 e 1979, a média dos índices de reprovação permaneceu alta. 
Esses dados revelam que as reprovações estavam diretamente relacionas a condição social dos alunos que formavam novo público que avançariam em sua escolarização. Muitos desses alunos, estavam retornando aos bancos escolares pois haviam parado de estudar para trabalharem e colaborar com o sustento da família. Mas também é indício do seletivo sistema educacional dual que o Brasil implantara desde o seu início, que expulsava por meio de educação tradicional, aqueles indivíduos que não portavam uma cultura escolar ligada às famílias mais tradicionais e que não tinham condições de investirem na formação escolar de seus filhos.

\section{Considerações Finais}

O estudo da história do Colégio Comercial Oficial de Ituiutaba buscou contribuir com a ampliação das discussões historiográficas sobre as instituições escolares no município, incrementando o conhecimento relacionado à história desse tipo de escola do Triângulo Mineiro. Nos últimos anos, foram concluídas pesquisas e publicados trabalhos referentes ao Colégio São José, Instituto Marden, Colégio Santa Tereza, Educandário Espírita Ituiutabano e, por último, uma pesquisa sobre o ensino primário noturno da Escola Municipal Machado de Assis (SOUZA; RIBEIRO, 2009). Todas foram instituições de ensino do município que antes e no decorrer na década de 1960 ofereciam cursos profissionalizantes e, com exceção da Escola Municipal Machado de Assis, eram privadas. Ressalva-se nesse grupo o Educandário Espírita Ituiutabano que era mantido pela iniciativa privada, mas sem a cobrança de mensalidades. Assim, na época, era restrito o acesso de grande parte da população a essas escolas. Nos trabalhos mencionados não se privilegiou a pesquisa relacionada especificamente ao ensino técnico profissional, em especial aos cursos de comércio, um dos focos de discussão deste estudo.

Buscamos evidenciar nesse trabalho que muito embora, esse colégio fosse aberto a todas as classes sociais, foram os desfavorecidos que mais frequentaram essa escola, cuja finalidade com a difusão do ensino profissional era o de atender a demanda por formação técnica visando ao progresso local. Os cursos profissionais, exceto o Normal do Santa Teresa, eram noturnos e atendiam, portanto, aquela parcela de alunos que não podia estudar durante o dia, ou seja, os jovens trabalhadores. Por ser um público trabalhador e que retornava a escola para prosseguir seus estudos depois de anos, os resultados do desempenho eram muito desfavoráveis, gerando altos índices de reprovação e consequentemente abandono, contribuindo para o reforço do sistema dual de ensino.

Mesmo assim, esse colégio passou a ser uma alternativa restrita mas pública de continuidade da formação escolar e não apenas para a cidade de Ituiutaba. Ressalta-se, também, que a demanda por educação profissional vinha da população de outros municípios e distritos adjacentes e integrantes da microrregião, sendo eles: Capinópolis, Ipiaçu, Gurinhatã, Santa Vitória, Cachoeira Dourada e Monte Alegre de Minas, que enviavam seus alunos diariamente, provendo o transporte escolar.

Não há dúvidas quanto à importância da pesquisa e análise da história das instituições escolares como expressão de um contexto mais amplo. Assim, a trajetória do Comercial expressa os novos rumos políticos preponderantes no cenário nacional que forçariam a adoção de reformas educacionais que tornassem o ensino mais alinhado com as exigências do capital industrial. A partir de 1964, ocorreria uma redefinição do Estado e de suas funções, com o alijamento da população da esfera das decisões, e criando-se condições políticas e sociais para que a economia se expandisse no sentido desejado, assim, reforçou-se o executivo, centralizou-se a administração pública e buscou-se cessar o protesto social. A educação nesse projeto era, mais do que nunca, uma estratégia, 
especialmente pela ambição de se criar um grande exército de técnicos prontos a contribuírem com o novo projeto de nação apoiado sobre o capitalismo monopolista.

Para a realização desse trabalho, além das fontes bibliográficas, documentos do acervo da escola, jornais da época, também localizamos um acervo de fontes iconográficas que permitiram visualizar com mais proximidade o processo de criação e implantação do Colégio Comercial Oficial de Ituiutaba. Aos resultados das reflexões a partir das fontes impressas no decorrer da pesquisa, agregamos depoimentos de sujeitos que foram testemunhas dessa parte da história educacional local, possibilitanto o cruzamento das informações, enriquecendo o processo de compreensão da história do colégio, a partir do recurso a memória.

\section{Referências}

ARANHA, Maria Lúcia de Arruda. História da Educação e da Pedagogia: Geral e Brasil. 3.ed. São Paulo: Moderna, 2006

BARROS JÚNIOR, Cícero. Ituiutaba, 27 de fevereiro de 2012. 1 fita cassete (60 min.). Entrevista concedida a nós. Ex-diretor do Colégio Comercial Oficial de Ituiutaba por dezessete anos.

BRASIL, IBGE. Anuário estatístico do Brasil 1967. Rio de Janeiro: IBGE, v. 28, 1967. IBGE. 1959

IBGE. Enciclopédia dos Municípios Brasileiros, XXV volume, Rio de Janeiro:

CASTANHO, Sérgio. Educação para o trabalho no Brasil Colônia. HISTEDBR on line Disponível em:

<http://www.histedbr.fae.unicamp.br/navegando/artigos_frames/artigo_099.html.> Acesso em: abril de 2011.

DELFHINO, Fátima Beatriz de Benedictis. A educação profissional: contrapondo entre as políticas educacionais e o contexto produtivo. São Paulo: Ícone. 2010.

FONSECA, Celso Suckow da. História do ensino industrial no Brasil. Rio de Janeiro: Escola Técnica Nacional. v. 1. 1961.

Nacional. v. 2. 1962.

História do ensino industrial no Brasil. Rio de Janeiro: Escola Técnica

GENTILI, Pablo. Três teses sobre relação trabalho e educação em tempos neoliberais. In:

LOMBARDI, José Claudinei; SAVIANI, Demerval; SANFELICE, José Luis [orgs.].

Capitalismo, Trabalho e Educação. Campinas: Autores Associados. 2002. p. 53.

INÁCIO FILHO, Geraldo; SOBRINHO, Vicente Batista de Moura. A massificação do ensino em Uberlândia: imprensa como fonte e objeto e investigação histórica (1940-1960). Anais do V Congresso de Ciências Humanas, Letras e Artes. UFOP. 2001. Disponível em: <http://www.ichs.ufop.br/conifes/anais/EDU/edu1714.htm> Acesso em: julho de 2011.

LUZIA, Iderlindo Joaquim. Ituiutaba, 19 de janeiro de 2012. 1 fita cassete (60 min.). Entrevista concedida a nós. ex-aluno do Instituto Marden, e formado na primeira turma de Técnicos em Contabilidade do Colégio Comercial Oficial de Ituiutaba (1967). 
PAIVA, Vanilda. Sobre o Conceito de "Capital Humano". Cadernos de Pesquisa, São Paulo, n.113, p. 185-191, jul. 2001.

PREFEITURA MUNICIPAL DE ITUIUTABA, Secretaria de Educação e Cultura de Ituiutaba. 2001 ano do centenário. Ituiutaba: Egil. 2001. p.128.

MAGALHÃES, Justino. A História das instituições educacionais em perspectiva. In: GATTI JR., Décio; INÁCIO FILHO, Geraldo. (Org.). História da Educação em perspectiva: ensino, pesquisa, produção e novas investigações. Campinas, SP, Autores Associados.Uberlândia: EDUFU, 2005. p.98.

NASCIMENTO, Osvaldo Viera do. Cem anos de ensino profissional no Brasil. Curitiba: Ibpex. 2007.

NOSELLA, Paolo; BUFFA, Ester. As pesquisas sobre instituições escolares: o método dialético marxista de investigação. Eccos - Revista Científica, São Paulo, v. 7, n. 2, p. 351358, jul./dez. 2005. p.351-352.

NOVAIS. A. S. História antiga de Ituiutaba. Ituiutaba. Edição do Autor. 1974.

ROMANELLI, Otaíza de Oliveira. História da Educação no Brasil (1930/1973). 30 ed. Petrópolis: Vozes. 2006.

SANTOS, Jailson Alves dos. A trajetória da educação profissional. In: LOPES, Eliane Marta Teixeira; FARIA FILHO, Luciano Mendes de; VEIGA, Cynthia Greive (Orgs). 500 anos de educação no Brasil. 3ed. Belo Horizonte: Autêntica, 2007.

SOUZA, Sauloéber Társio de. "O Universo Escolar nas páginas da imprensa tijucana (Ituiutaba-MG, anos de 1950 e 1960)" In.: Cadernos de História da Educação, v. 09, n. 02, julho-dezembro/2010.

SOUZA, Sauloéber Társio de; RIBEIRO, Betânia de Oliveira Laterza (Orgs.). Do público ao privado, do confessional ao laico: a história das instituições escolares de Ituiutaba do século XX. Uberlândia: Edufu, 2009

SAVIANI, Demerval. História das idéias pedagógicas no Brasil. 2 ed. Campinas: Autores Associados. 2008.

SILVA, Dalva Maria de Oliveira. Memória: Lembrança e Esquecimento. Trabalhadores Nordestinos no Pontal do Triângulo Mineiro (Décadas de 1950 e 1960). Dissertação de Mestrado: PUC-SP. 1997.

VIÑAO FRAGO, Antonio. El Espacio y El tiempo escolares como objeto histórico. In. Contemporaneidade e Educação. Ano V. n 7. $1^{\circ}$ Sem/2000. p. 98.

Recebido em abril-13

Aprovado em junho-13 


\section{Notas}

${ }^{1}$ No período de quatro anos foram promulgados os seguintes: Decreto-lei $n^{\circ} 4.048$, de 22/01/1942 - cria o Serviço Nacional de Aprendizagem Industrial (SENAI); Decreto-lei nº 4.073, de 30/01/1942 - Lei Orgânica do Ensino Industrial; Decreto-lei no 4.244, de 09/04/1942 - Lei Orgânica do Ensino Secundário; Decreto-lei $n^{\circ}$ 6.141, de 28/12/1943 - Lei Orgânica do Ensino Comercial; Decreto-lei no 8.529, de 02/01/1946 - Lei Orgânica do Ensino Primário; Decreto-lei no 8.530, de 02/01/1946 - Lei Orgânica do Ensino Normal; Decretos-lei no 8.621 e 8.622, de 10/01/1946 - Criam o Serviço Nacional de Aprendizagem Comercial (SENAC) e, por fim, o Decreto-lei n 9.613, de 20/08/1946 - que trata da Lei Orgânica do Ensino Agrícola (ROMANELLI, .

2 BRASIL. Lei $\mathrm{N}^{\mathrm{o}} 5.540$, de 28 de novembro de 1968. Fixa normas de organização e funcionamento do ensino superior e sua articulação com a escola média, e dá outras providências. Disponível em: < http://www6.senado.gov.br/legislacao/ListaTextoIntegral.action?id=75564\&norma=102363 > Aceso em: 1 mar. 2012.

3 MINAS GERAIS. Lei $\mathrm{n}^{\circ}$ 4.941, de 12 de setembro de 1968. Fixa normas para designação de estabelecimentos de ensino médio, mantidos pelo Estado. 1968. O artigo $2^{\circ}$ da lei descreve que se designará [...] "Colégio Estadual" os estabelecimentos de cursos de segundo ciclo; o Caput do artigo descreve que as designações serão de acordo com a normas da lei e que expressão de "Colégio Estadual" poderá seguir-se de designação específica, de homenagem ou evocação, ou será mencionada a localidade em que se situa o estabelecimento.

4 A falta de prédios próprios para as escolas de Ituiutaba, as precárias condições causadas por falta de estrutura das escolas anexadas a outras (Idelfonso Mascarenhas e Bias Fortes) são relatadas, com base em notícias da imprensa da época (SOUZA, 2010).

${ }^{5}$ Livro de Atas das Reuniões do Corpo Docente. Ata de reunião do dia 12 de fevereiro de 1970. p. 28.

${ }^{6}$ Livro de Atas das Reuniões do Corpo Docente. Ata de reunião do dia 9 de março de 1968. p. 3. 